\title{
Temperature Effect on Skin Adhesion, Cell Wall Enzyme Activity, Lignin Content, Anthocyanins, Growth Parameters, and Periderm Histochemistry of Sweetpotato
}

\author{
Lucia E. Villavicencio, Sylvia M. Blankenship ${ }^{1}$, and G. Craig Yencho \\ Department of Horticultural Science, North Carolina State University, Raleigh, NC 27695 \\ Judith F. Thomas \\ Department of Plant Biology, North Carolina State University, Raleigh, NC 27695 \\ C. David Raper \\ Department of Soil Science, North Carolina State University, Raleigh, NC 27695
}

\begin{abstract}
AdDitional INDEX words. Ipomoea batatas, skinning, skin loss, 'Beauregard', polygalacturonase, pectin methylesterase, epidermis

Abstract. Sweetpotatoes [Ipomoea batatas (L.) Lam.] often experience significant epidermal loss during harvest and postharvest handling. Skin loss causes weight loss, shriveling of the root surface, and increased susceptibility to pathogen attack as well as poor appearance. It is not known if sweetpotatoes show variation in skin adhesion, cell wall enzyme activity and components, and growth parameters with growth temperature or if skin loss can be explained on the basis of variation among these variables. Skin adhesion, polygalacturonase (PG) and pectin methylesterase (PME) activity, lignin, anthocyanin, and dry matter content were measured in the periderm of 'Beauregard' roots grown at various temperatures under controlled conditions. Biomass dry matter content, storage root yield, root length, diameter, and weight at harvest were recorded. Histochemical and anatomical characteristics of periderm of roots were studied. Growth temperature affected skin adhesion, PG and PME activity, periderm and biomass dry matter content, yield, storage root weight, and diameter. High temperatures $\left(34 / 31{ }^{\circ} \mathrm{C}\right.$ day/night) yielded roots that were smaller and more resistant to skin loss. These roots had a periderm composed of more cell layers with a lower dry matter content than roots grown at lower and intermediate temperatures $\left(27 / 24^{\circ} \mathrm{C}\right.$ and $\left.20 / 17^{\circ} \mathrm{C}\right)$. In cured roots, the correlation between skin adhesion and $\mathrm{PG}$ activity was negative $(r=0.544, P=0.0006)$ and positive between skin adhesion and PME $(r=0.319, P=0.05)$. For most of the variables studied, the interaction between growing temperature and curing was significant. Curing improved skin adhesion, but the effect of curing was dependent on the root growth temperature. The periderm of roots grown at higher temperatures was thicker and had more layers than that of roots grown at lower temperatures. Histochemical studies of the periderm of sweetpotato showed that the anatomical and structural composition of the cell walls differ depending on growth temperature.
\end{abstract}

Sweetpotato is one of the major tropical root crops produced throughout the world and it is widely distributed in the tropical and temperate regions of Africa, Asia, and America. It is also the leading vegetable crop grown in North Carolina. One of the problems in postharvest handling of sweetpotato roots is the loss of the epidermis/skin from the surface of the root, referred to as "skinning." During skinning, the superficial layers of the periderm separate from underlying tissue, leading to an increased rate of moisture loss, weight loss, shriveling of the root surface, increased susceptibility to pathogen attack, and unattractive appearance. In North Carolina, and in the United States in general, one of the most popular cultivars is 'Beauregard' due to its smooth skin, color, and high yields. This cultivar, however, is very prone to skin loss during harvest and handling.

Received for publication 17 Nov. 2006. Accepted for publication 26 June 2007. From a dissertation submitted by the senior author (L.E.V.) in partial fulfillment of the requirements for the $\mathrm{PhD}$ degree.

Mention of a trademark or proprietary product does not constitute a guarantee or warranty of the product and does not imply its approval to the exclusion of other products that may also be suitable.

${ }^{1}$ Corresponding author. E-mail: sylvia_blankenship@ncsu.edu.
There are very few studies on the mechanisms and factors involved in sweetpotato skin adhesion. Skinning appears to involve breakage of the longitudinal walls of periderm cells and removal of the skin by breakage of the radial walls of phellogen cells, and it is affected by environmental conditions (Birnbaum, 1970). Freshly harvested sweetpotatoes have a thin skin that is very susceptible to breakage, with curing and storage usually improving skin toughness (Boyette et al., 1997). Curing is done by placing the roots at $29.4{ }^{\circ} \mathrm{C}$ and $85-90 \%$ relative humidity for 4-7 d (Walter and Schadel, 1982). In potato (Solanum tuberosum L.), it is the phellem portion of the periderm that is referred to as skin. The phellem is a lateral meristematic tissue that gives origin to the periderm (Lulai, 2002). Lulai and Freeman (2001) showed that skin thickening and suberization were not the source of development of resistance to skinning in potato. Furthermore, it was the tissue separation occurring in the phellogen layer of immature periderm that caused the skinning injury to appear. In potato, it is the strength of the radial walls of the phellogen, determined by their lability and proneness to fracture, that determines the resistance to skinning (Lulai, 2002). 
There is no information on how cell wall enzyme activity varies in sweetpotato. Pectinases are particularly important during fruit ripening due to their effect on the cell walls. These enzymes have been well characterized in fruit, and their role in fruit softening is well known. Pectin methylesterase (PME) and polygalacturonase (PG) are cell wall enzymes that catalyze pectin modification and disassembly (Hadfield and Bennett, 1998), a process that occurs in many stages of plant development that require cell separation.

PG is associated with abscission (Taylor et al., 1990), which is the result of the dissolution of cell walls between adjacent cells (Sexton and Roberts, 1982), as well as fruit dehiscence (Sanders et al., 2001), and it may be involved in cell expansion and other cell wall related processes (Sirit et al., 1996). In fruit, PG and PME affect the integrity of the middle lamella of the cell walls, which controls cell-to-cell adhesion (Brummell and Harpster, 2001).

PG catalyzes the hydrolytic cleavage of galacturonide linkages in the pectin matrix and they can have, depending on enzyme specificity, endo or exo action. Experiments with transgenic tomato plants (Solanum lycopersicum L.) have demonstrated that PG is responsible for a major component of polyuronide solubilization and depolymerization during ripening, but $\mathrm{PG}$ was not responsible for fruit softening. However, in these studies, suppression of PG activity was not complete (Brummell and Harpster, 2001). Postharvest factors in transgenic tomato fruit with reduced PG activity were improved (Schuch et al., 1991).

PME activity is a key control point for assembly and disassembly of the pectic matrix (Willats et al., 2001). PME is involved in de-esterification of pectins. Before secretion, pectin domains become esterified, mostly by methylesters. Pectin de-esterification via PME activity can result in crosslinking of pectin molecules with calcium ions and the formation of semirigid gels (Levy and Staehelin, 1992; Willats et al., 2001). In fruit, calcium cross-linking of pectins is believed to increase firmness. However, pectin de-esterification can also result, in some cases, in increased susceptibility to PG activity because the substrate for PG in the cell wall is mainly deesterified homogalacturonans (Carpita and Gibeaut, 1993). In this case, PME activity would correlate with PG activity and loss of firmness and increased fruit softening.

It is generally accepted that lignins, defined as phenolic polymers found in some plant cell walls, confer compressive strength, resistance to microbial degradation and water impermeability to the matrix of the cell walls (Whetten et al., 1998). The outer peridermal cells of sweetpotato become partly lignified during growth and are progressively sloughed off. The phellogen layer, however, remains active until harvest, and its activity causes the thickness of the periderm layer to remain constant (Artschwager and Starrett, 1931). Lignins may be involved in abscission by either increasing mechanical strength of the cell walls or by protecting neighboring cells from hydrolytic enzymes produced in the abscission layer (Sexton and Roberts, 1982).

Because skin loss occurs due to breakage of the cell walls of peridermal cells, lignin content and PG and PME activities could be part of the processes or factors that lead to increased or decreased skin adhesion in sweetpotato roots. If this is the case, skin adhesion might correlate with these variables, making it possible to use them as indicators of susceptibility to skinning.
The objective of this study was to investigate the effect of low, medium, and high temperatures on skin adhesion, PG and PME activity, lignin content, and growth parameters of plants and roots of 'Beauregard' sweetpotato. Correlations between these variables were investigated to determine if skin loss could be related to the activity of cell wall enzymes, lignin content, or variation in growth parameters of the plants, roots, or periderm cell walls of the roots at various growth temperatures.

\section{Materials and Methods}

The study was conducted at the Southeastern Plant Environment Laboratory in Raleigh, NC. Sweetpotato cuttings of 'Beauregard' were obtained from the micropropagation unit at North Carolina State University, Raleigh. Eighteen cuttings, each four nodes in length, were planted in pots $0.017 \mathrm{~m}^{3}$ in volume. Sterilized river-bottom sand was used as growing media. Pots were placed in an A-type growth chamber under controlled conditions (Thomas and Downs, 1991) and at 27/ $24{ }^{\circ} \mathrm{C}$ day/night temperature. Plants were watered twice per day with standard nutrient solution (Thomas and Downs, 1991). Thirty days after planting, the plants were divided into three groups of six plants each, and each group was placed in B-type growth chambers (Thomas and Downs, 1991) at 34/31 ${ }^{\circ} \mathrm{C}, 27 /$ $24{ }^{\circ} \mathrm{C}$, and $20 / 17^{\circ} \mathrm{C}$ day/night temperature. Plants were watered twice per day with deionized water and fertilized twice per month with standard nutrient solution. All chambers were kept at a 14-h photoperiod. Once roots reached canner size, they were harvested for each treatment. The experiment was replicated in time. The first experiment was harvested $120 \mathrm{~d}$ after planting, while the second experiment was harvested $140 \mathrm{~d}$ after planting. Variables measured included skin adhesion, PG and PME activities, lignin and dry matter content of the root periderm, length, weight, and diameter of storage roots, dry matter content of the biomass (leaves and stems), and yield of storage roots. There were six plants per treatment, and a maximum of three roots per plant were used to measure all the variables considered. In some cases, only two roots per plant were necessary. Skin adhesion, PG and PME activities, yield, root diameter, and root weight were measured right after harvest. PG and PME were measured on the same roots used for determining skin adhesion. Variables such as periderm dry matter content and lignin content required material preparation, such as drying and grinding, and were measured within $5 \mathrm{~d}$ of harvesting. Roots were held in cold storage at $14{ }^{\circ} \mathrm{C}$ and $95 \%$ RH during this period. Three roots per plant per treatment were washed, towel-dried, and cured for $6 \mathrm{~d}$ by placing them in a chamber at $25{ }^{\circ} \mathrm{C}$ and $85 \% \mathrm{RH}$. The same variables described above were measured in cured roots. Sections from cured and uncured roots were placed in fixative to be used for microscopy procedures to determine periderm anatomy and structure and to make qualitative observations of cell wall components. The experimental design was a split plot design with three temperature levels and two levels of curing: uncured or cured roots. Data presented are from duplicate experiments.

Skin ADHesion. To measure skin adhesion, one root from each of six plants per treatment was randomly selected. Skin adhesion was measured as water pressure in kilograms per square meter required to break the skin (Blankenship and Boyette, 2002; Bouwkamp et al., 1972). The higher the water 
pressure needed to break the skin, the more resistant the roots were to skinning (stronger skin adhesion). Skin adhesion was quantified by using a device that directs a jet of water under increasing pressure over time to the root surface from a constant distance. Breakage of the skin is determined visually, and once it occurs the jet of water is stopped and the water pressure is automatically recorded in a computer attached to the device. The roots used for the skin test were also used for determination of enzyme activity.

EnZYMe EXTRaction. Roots were washed and towel dried. A 3-g sample of tissue from the root surface was used. Periderm tissue was excised from the midsection located between the proximal (stem) and distal (root) ends of the roots. Thickness of the tissue excised was no more than $1 \mathrm{~mm}$. Because these roots had been previously used for the skin test, the section of the root that was wounded by the water jet was not used for the enzyme activity assay. The tissue was prepared for enzyme extraction within $1 \mathrm{~h}$ after completion of the skin adhesion test. Saltextractable protein was prepared as described in Huber and O'Donoghue (1993). The freshly excised tissue was homogenized in $20 \mathrm{~mL}$ of cold ethanol and centrifuged twice for $15 \mathrm{~min}$ at $4{ }^{\circ} \mathrm{C}$. The pellet was suspended in $15 \mathrm{~mL}$ of $1.2 \mathrm{M} \mathrm{NaCl}$ in $50 \mathrm{~mm}$ Tris, $\mathrm{pH}$ 7.0. The suspension was incubated for $30 \mathrm{~min}$ in an ice bath. After incubation, the sample was centrifuged for $15 \mathrm{~min}$ and then filtered through Miracloth (Calbiochem, San Diego). The extract was held on ice for up to $3 \mathrm{~h}$, until assayed for PG and PME activity.

EnzyMe ACTIVITy. PG was determined using the method of Milner and Avigad (1967). One-half milliliter of extract was incubated with polygalacturonic acid substrate $\left(2 \mathrm{mg} \cdot \mathrm{mL}^{-1}\right)$ at $34{ }^{\circ} \mathrm{C}$ for $30 \mathrm{~min}$. The reaction was stopped by adding copper reagent. After arsenomolibdate reagent was added, PG activity was determined reductometrically. Absorbance was measured at $600 \mathrm{~nm}$ (Milner and Avigad, 1967) using a spectrophotometer (Spectronic 200; Bausch \& Lomb, Rochester, NY). Enzyme activity was expressed as micromoles of galacturonic acid reducing equivalent per gram of fresh tissue per minute. Galacturonic acid was used as standard.

PME activity was determined by the method described by Wood and Siddiqui (1971) with modifications. One-half milliliter of extract was incubated with $0.4 \mathrm{~mL}$ of citrus pectin substrate $\left(2 \mathrm{mg} \cdot \mathrm{mL}^{-1}\right)$ at $60{ }^{\circ} \mathrm{C}$ for $1 \mathrm{~h}$. The reaction was stopped by adding $0.5 \mathrm{~mL}$ of $2 \mathrm{~N}$ sulfuric acid and $0.2 \mathrm{~mL}$ of $2 \%$ $(\mathrm{w} / \mathrm{v})$ potassium permanganate. Samples were swirled gently and placed in an ice bath for $15 \mathrm{~min}$. After incubation, $0.2 \mathrm{~mL}$ of sodium arsenite in $0.12 \mathrm{~N}$ sulfuric acid and $0.6 \mathrm{~mL}$ of deionized water were added. The samples were left at room temperature for $1 \mathrm{~h}$, and then $2 \mathrm{~mL}$ of $0.02 \mathrm{M}$ acetyl acetone in $2 \mathrm{M}$ ammonium acetate and $0.05 \mathrm{~m}$ acetic acid were added. The tubes were incubated for $15 \mathrm{~min}$ at $60{ }^{\circ} \mathrm{C}$ and then cooled to room temperature. Absorbance was measured at $412 \mathrm{~nm}$ in a spectrophotometer (Spectronic 200). Methanol was used as the standard, and activity was expressed as micromoles of methanol released per gram of fresh tissue per minute.

Lignin CONTENT. Roots were washed and towel-dried. Tengram samples of tissue from the surface of each root were weighed and dried overnight a $100{ }^{\circ} \mathrm{C}$. The same roots used for determination of skinning and enzyme activity were used for determination of lignin. When $10 \mathrm{~g}$ of tissue was not available from these roots, additional roots from the same plant were used to complete the sample. Thickness of the tissue excised was no more than $1 \mathrm{~mm}$. The dry tissue was ground to a fine powder and kept at $4{ }^{\circ} \mathrm{C}$ for no more than 2 weeks. Powder was prepared for lignin determination as described by Morrison (1972). One gram of powder was heated with $70 \mathrm{~mL}$ of distilled water in a water bath at $70{ }^{\circ} \mathrm{C}$ for $30 \mathrm{~min}$ with occasional shaking and then filtered hot through Whatman \# 4 filter paper (Fisher Scientific, Pittsburgh). The sample was washed twice with distilled water and three times each with ethanol, acetone, and diethyl ether. The residue was transferred to a petri dish and dried overnight at $47^{\circ} \mathrm{C}$. Lignin content was measured as described by Iiyama and Wallis (1990). One hundred fifty milligrams of the dried residue were mixed with $4 \mathrm{~mL}$ of a $25 \%(\mathrm{v} / \mathrm{v})$ solution of acetyl bromide in glacial acetic acid and $0.16 \mathrm{~mL}$ of $70 \%$ perchloric acid. The mixture was digested for $30 \mathrm{~min}$ in a water bath at $70{ }^{\circ} \mathrm{C}$ with occasional stirring. After digestion was completed, $20 \mathrm{~mL}$ of glacial acetic acid was added. A blank of acetyl bromide reagent and perchloric acid was used. One milliliter of each sample solution and $0.5 \mathrm{~m}$ hydroxylamine hydrochloride were added to tubes containing $6 \mathrm{~mL}$ of glacial acetic acid and $4 \mathrm{~mL}$ of $0.3 \mathrm{M} \mathrm{NaOH}$ and left for $15 \mathrm{~min}$ at room temperature. Absorbance was measured at $280 \mathrm{~nm}$ using a spectrophotometer (Spectronic 200). Lignin content was determined as milligrams per milliliter from a standard curve using a regression equation. The standard curve was prepared as described by Fukushima and Dehority (2000). Sweetpotato periderm powder was prepared by drying periderm tissue overnight at $100{ }^{\circ} \mathrm{C}$ and grinding the material to fine powder. The material was washed as described by Morrison (1972) and dried overnight at $47{ }^{\circ} \mathrm{C}$. Two grams of the sample was mixed with $6 \mathrm{~mL}$ of a $20 \%(\mathrm{v} / \mathrm{v})$ solution of perchloric acid in acetic acid. Thirty milliliters of a $25 \%(\mathrm{v} / \mathrm{v})$ solution of acetyl bromide in glacial acetic acid was added, and the mixture was incubated in a $70{ }^{\circ} \mathrm{C}$ water bath for $30 \mathrm{~min}$ with occasional mixing. After digestion, the sample was centrifuged for $10 \mathrm{~min}$ and the supernatant cooled in an ice water bath to solubilize lignin. An excess of cold distilled water was added to precipitate lignin, and the precipitate was collected by filtration through Whatman \# 4 filter paper (Fisher Scientific). The precipitate was solubilized in dioxane, filtered, and dried twice. A mixture of anhydrous ether and petroleum ether $(80: 20)$ was added to the final mixture of lignin in dioxane. The mixture was filtered and washed with petroleum ether. The resulting powder was lignin. To obtain the standard curve, the powder was corrected for protein and carbohydrates (Viles and Silverman, 1949). The equivalent to $30 \mathrm{mg}$ of lignin powder was dissolved in acetyl bromide acid reagent and perchloric acid. The sample was treated as described for lignin digestion, and increasing volumes of the final mixture were pipetted into tubes containing acetic acid and $\mathrm{NaOH}$. Absorbance was measured at $280 \mathrm{~nm}$ using a spectrophotometer (Spectronic 200).

Anthocyanin Content. Anthocyanins were measured only for the second replicate of the experiment. Six roots per combination of growth temperature and curing level were used. The content of anthocyanins in the periderm of sweetpotatoes was determined as described by Shi et al. (1992). Roots were washed and towel-dried. A 2-g sample of periderm tissue from the root surface was weighed and placed in a $25-\mathrm{mL}$ erlenmeyer flask. Twenty-five milliliters of a $1 \% \mathrm{HCl}$ in methanol solution was added, and the flask was capped with a marble. The mixture was boiled for $10 \mathrm{~min}$ and cooled at room temperature for $1 \mathrm{~h}$. Absorbance was measured at $530 \mathrm{~nm}$ using a spectrophotometer (Spectronic 200). Distilled water was used as a blank. 
Dry MATter CONTENT. Biomass composed of leaves and stems was dried at $75^{\circ} \mathrm{C}$ until a constant weight was reached. For dried matter content of the periderm, roots were washed, towel-dried, and allowed to air dry for $1 \mathrm{~h}$. Tissue from the root surface was collected and placed in an oven at $75^{\circ} \mathrm{C}$ until constant weight was reached. Thickness of the tissue excised was no more than $1 \mathrm{~mm}$. Dry matter content was determined as the difference between the initial fresh weight and the dry weight and is expressed as a percentage.

YIELD. Masses of individual storage roots were recorded and added to obtain total yield per plant. Only roots $>25 \mathrm{~mm}$ in diameter were weighed.

ROOT WEIGHT, LENGTH, AND DIAMETER. Two roots from each of six plants per treatment were selected and weighed. Length was taken in centimeters from root tip to root end. Diameters at the widest section of the root were taken in millimeters.

Microscopy. Roots were washed and towel-dried. Sections from the midportion of the roots (cured and uncured) with intact skin were excised. Tissue blocks were trimmed to obtain pieces of $\approx 2 \mathrm{~mm}$ wide, $3 \mathrm{~mm}$ long, and no more than $1 \mathrm{~mm}$ thick. Blocks were fixed and stored in formaldehyde/acetic acid (FAA). Sections were subjected to a dehydration series by placing them for $1 \mathrm{~h}$ each in 50\%,70\%, 95\%, and 100\% ethanol. An infiltration series using ethanol and benzoyl peroxide (catalyst) in JB-4 solution A (0.9 g in $100 \mathrm{~mL}$ ) (Polysciences, Warrington, PA) was performed. Sections were placed for $1 \mathrm{~h}$ in mixtures of ethanol and catalyzed solution $A$ in $3: 1,1: 1$, and 1:3 proportions. Sections were then placed in vials containing $100 \%$ catalyzed solution A and 5\% dimethyl sulfoxide (DMSO) and infiltrated for $1 \mathrm{~h}$. The last infiltration step was done by placing sections in $100 \%$ catalyzed solution A and 5\% DMSO overnight. Sections were placed in molds and plastic resin solution (JB-4 catalyzed solutions A and B, 30:1) was added to fill each cell. The molds were placed in a desiccator containing dry ice, and a slight vacuum was pulled. After the dry ice sublimated, the desiccator was sealed and the resin allowed to polymerize for $2 \mathrm{~h}$. Molds were transferred to an oven at $60{ }^{\circ} \mathrm{C}$ overnight. Transverse sections $8 \mu \mathrm{m}$ thick were cut on a Porter-Blum MT2 ultramicrotome (Ivan Sorvall, Norwalk, CT) and stained with aqueous toluidine blue and basic fuchsine. Sections were viewed in a Nikon Biophot compound scope (Nikon, Tokyo) and photographed using a SPOT cooled color digital camera (Diagnostic Instruments, Sterling Heights, MI).

Thickness AND NUMBER OF LAYERS OF THE PERIDERM. Thickness of the periderm in sections of cured roots was measured using a micrometer. Number of periderm layers was visually determined. Three sections obtained from three different roots per growth temperature were used.

DAta analysis. Data were analyzed as a split plot design using the analysis of variance (ANOVA) procedure of SAS (SAS Institute, Cary, NC). LSD values were calculated at the 5\% level. Correlations between tested variables were established using the CORR procedure of SAS.

\section{Results and Discussion}

For most of the variables studied, the interaction between growth chamber temperature and curing (main effects) was significant. In these cases, the main effects are not reported but the mean separation between groups, namely between temperature and curing levels (cured or uncured roots), is given. When the interaction between temperature and curing was not significant, the main effects were tested and the mean separation is reported for each temperature level, regardless of the curing level. The data are discussed and presented for each variable studied. Because yield and biomass dry matter content were determined at harvest, curing levels do not apply. Weight, length, and diameter of the root also are unaffected by curing levels; thus, only the effects of growth temperature on these variables are discussed. The interaction between temperature and curing levels was significant; thus the effect of temperature on skin adhesion is discussed separately for cured and uncured roots.

Skin adhesion and temperature were positively correlated (Table 1). Skin adhesion in freshly harvested roots (uncured) was higher in roots grown at higher temperatures compared with roots grown at lower temperatures (Fig. 1A). These results agree with a previous study in which high temperature and relative humidity accelerated the rate of division of phellogen cells in some cultivars, probably increasing skin toughness (Birnbaum, 1970). Similarly, Webster et al. (1973) found that peeling resistance was the highest for roots grown in warm, dry soils. In potatoes grown under controlled conditions, relative humidity hastened periderm maturation in freshly harvested tubers (Lulai and Orr, 1993). As periderm matures, phellogen activity decreases, and there is an inverse relationship between phellogen activity and resistance to skinning (Lulai and Freeman, 2001).

Table 1. Correlation coefficients and significance of growth temperature with skin adhesion, polygalacturonase activity (PG), periderm dry matter content (PDMC), weight and diameter of the roots, biomass dry matter content (BDMC), yield, lignin, anthocyanins, periderm thickness, and number of periderm layers in sweetpotato roots.

\begin{tabular}{|c|c|c|}
\hline & \multicolumn{2}{|c|}{ Temperature } \\
\hline & Uncured roots & Cured roots \\
\hline \multirow[t]{2}{*}{ Skin adhesion } & 0.944 & 0.777 \\
\hline & $* * *$ & $* * *$ \\
\hline \multirow[t]{2}{*}{ PG } & -0.280 & -0.682 \\
\hline & 0.098 & $* * *$ \\
\hline \multirow[t]{2}{*}{ PDMC } & -0.741 & -0.640 \\
\hline & $* * *$ & $* * *$ \\
\hline \multirow[t]{2}{*}{ Weight } & -0.498 & -0.438 \\
\hline & $* *$ & $* *$ \\
\hline \multirow[t]{2}{*}{ Diameter } & -0.448 & -0.440 \\
\hline & $* *$ & $* *$ \\
\hline \multirow[t]{2}{*}{ BDMC } & 0.476 & $\mathrm{~N} / \mathrm{A}$ \\
\hline & $* *$ & \\
\hline \multirow[t]{2}{*}{ Yield } & -0.400 & N/A \\
\hline & $*$ & \\
\hline \multirow[t]{2}{*}{ Lignin } & 0.400 & NS \\
\hline & $*$ & \\
\hline \multirow[t]{2}{*}{ Anthocyanins } & -0.995 & NS \\
\hline & $* * *$ & \\
\hline \multirow[t]{2}{*}{ Periderm thickness } & N/A & 0.893 \\
\hline & & $* * *$ \\
\hline \multirow[t]{2}{*}{ No. of periderm layers } & $\mathrm{N} / \mathrm{A}$ & 0.922 \\
\hline & & $* * *$ \\
\hline
\end{tabular}

Ns,*,**,*** Nonsignificant or significant at $P \leq 0.05,0.01$, or 0.001 , respectively. 

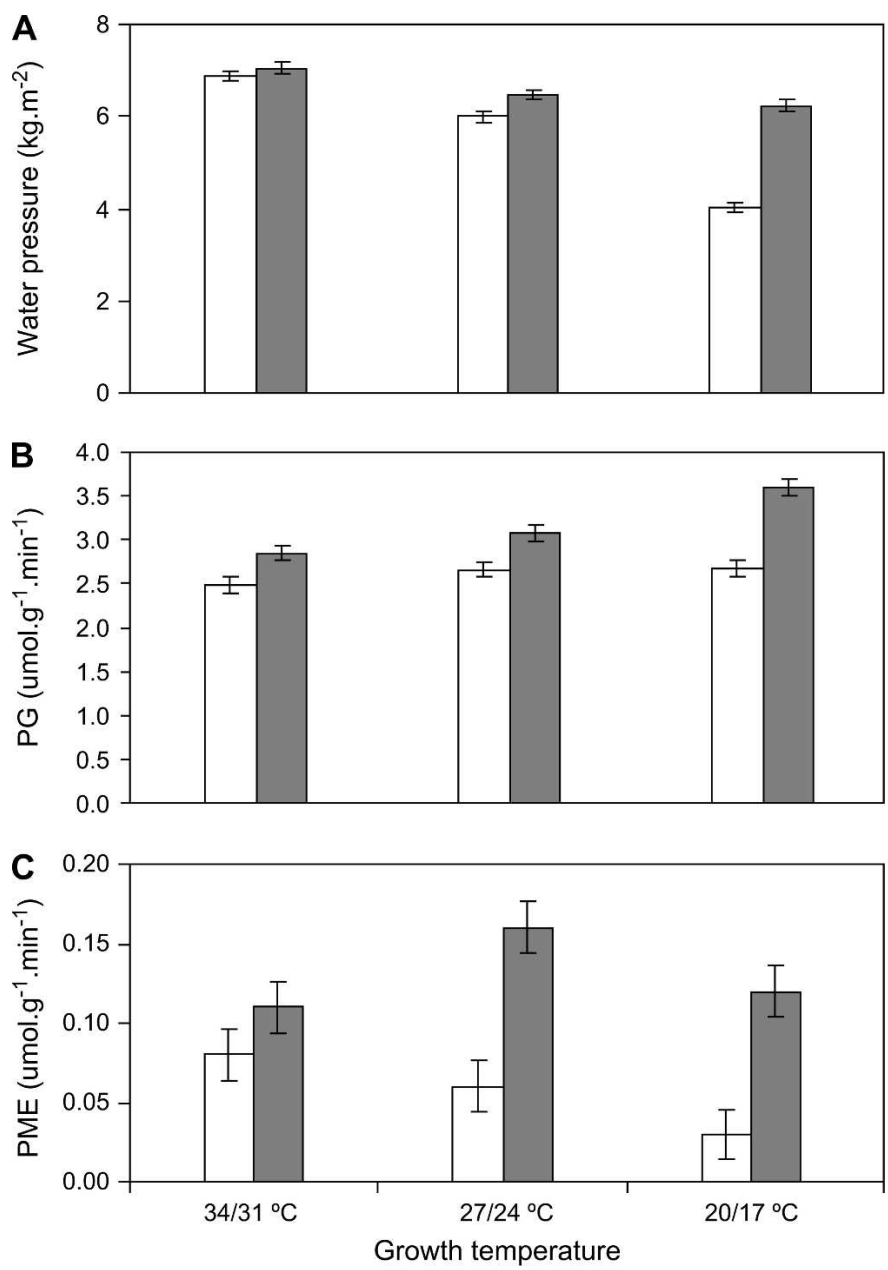

Fig. 1. Skin adhesion measured as a function of $(\mathbf{A})$ the water pressure needed to break the skin, (B) polygalacturonase (PG) activity, and (C) pectin methylesterase (PME) activity, in uncured (open bars) and cured (solid bars) roots of 'Beauregard' sweetpotato at various growth temperatures. Each data point represents the mean of 12 observations. Bars represent LSD values calculated at the $5 \%$ level.

The effect of curing on skin adhesion was modified by temperature during root growth. Curing did not reduce skinning of roots grown at higher temperatures, but it greatly improved the degree of skin adhesion of roots grown at lower temperatures, which were more susceptible to skinning right after harvest. These observations are consistent with the low, but still significant, positive correlation between skin adhesion and temperature in cured roots (Table 1). These results are in agreement with the reports that curing usually improves skin toughness (Boyette et al., 1997). Lulai and Orr (1993) found that in potato cultivars with higher vapor loss, periderm maturation was faster. Based on this, they inferred that the first layer of fully hydrated cells within the periderm (i.e., phellogen) would play an important part in tuber skin set and resistance to skinning. Curing probably increases the rate of water vapor loss from the periderm, hastening skin set. After curing, the degree of skinning would depend on the initial degree of skin adhesion. If the roots were susceptible to skinning because they were grown under colder growth conditions, the skin will not set to the same degree than if grown under warmer conditions, were water vapor losses, among other possible effects of warmer temperatures might have affected skin set.

PG activity varied between 2.49 and $3.6 \mu \mathrm{mol} \cdot \mathrm{g}^{-1} \cdot \mathrm{min}^{-1}$, and its pattern of activity only differed in cured roots, with a similar trend that was not significant for freshly dug (uncured) roots (Table 1 and Fig. 1B). There was a negative correlation between PG activity and growth temperature (Table 1). Curing increased $P G$ activity and in roots grown at lower temperatures, the effect was more pronounced than in roots grown at higher temperatures. Curing roots grown at low temperature decreased the susceptibility of the root to skinning to a greater extent than that of roots grown at higher temperatures. A significant, negative correlation was found between skin adhesion and PG activity in cured roots (Table 2). The effect of temperature on skin adhesion of the roots may be partially due to its effect on $\mathrm{PG}$ activity. Cleavage of pectic substances, which are the cement that hold cells together, catalyzed by PG could result in weakened cell-to-cell junctions and increased susceptibility of the skin to peel from the root surface.

$\mathrm{PME}$ activity ranged between 0.03 and $0.16 \mu \mathrm{mol} \cdot \mathrm{g}^{-1} \cdot \mathrm{min}^{-1}$. It was highest for freshly harvested roots grown at higher temperatures and decreased with decreasing growth temperature (Fig. 1C). Curing increased PME activity compared with uncured roots, and PME activity in cured roots was highest in roots grown at intermediate temperatures (Fig. 1C). PME is a key enzyme involved in the assembly and disassembly of the pectic matrix (Willats et al., 2001), as it is involved in deesterification of pectins. Before secretion, pectin domains become esterified, mostly by methylesters. Pectin de-esterification via PME activity results in cross-linking of pectin molecules via calcium ions and the formation of semirigid gels (Levy and Staehelin, 1992; Willats et al., 2001). In fruit, calcium cross-linking of pectins is believed to increase firmness.

Table 2. Correlation coefficients and significance between skin adhesion, polygalacturonase activity (PG), periderm dry matter content (PDMC), weight and diameter of the roots, biomass dry matter content (BDMC), periderm thickness, number of periderm layers, and yield in sweetpotato roots grown at various temperatures.

\begin{tabular}{lcc}
\hline & \multicolumn{2}{c}{ Skin adhesion } \\
\cline { 2 - 3 } & Uncured roots & Cured roots \\
\hline PG & NS & -0.544 \\
PME & 0.319 & $* * *$ \\
& & NS \\
PDMC & -0.681 & $*$ \\
& $* * *$ & -0.351 \\
Weight & -0.351 & $*$ \\
& $*$ & -0.504 \\
Diameter & $-0.352 *$ & $* *$ \\
& & -0.577 \\
Periderm thickness & N/A & $* * *$ \\
& & 0.633 \\
No. of periderm layers & N/A & $* *$ \\
& & 0.734 \\
BDMC & & $* * *$ \\
& & Yield \\
\end{tabular}

ws, ${ }^{* * *}, * * *$ Nonsignificant or significant at $P \leq 0.05,0.01$, or 0.001 , respectively. 
In this study, we found a positive correlation between PME activity and skin adhesion in fresh roots. After curing, however, PME activity did not correlate well with skin adhesion (Table 2). In tomato, PME isoforms differ in response to $\mathrm{pH}$ and cation concentration, and their activities vary considerably depending on stage of ripening and cultivar (Pressey and Avants, 1972). Curing may affect the physiology of sweetpotato roots and PME isoforms present in the root periderm or their patterns of action on pectins. It has been suggested that PME isoforms are differentially regulated throughout development and that their patterns of action depend on cell wall location, which results in differences in cell wall properties (Willats et al., 2001).

Periderm dry matter content varied between $15.9 \%$ and $23.9 \%$. Dry matter content was lower in roots grown under high temperatures compared with roots grown at lower temperatures for cured and uncured roots (Fig. 2A), which explains the negative correlation between periderm dry matter content and growth temperature (Table 1). Skin adhesion and periderm dry
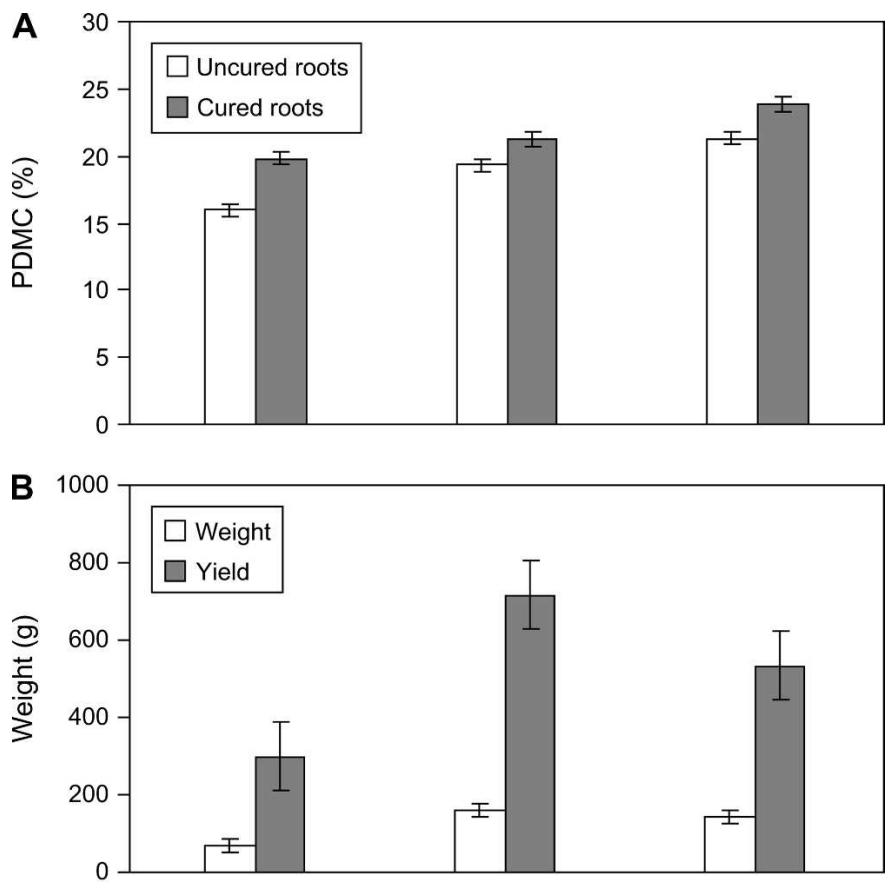

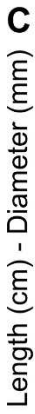

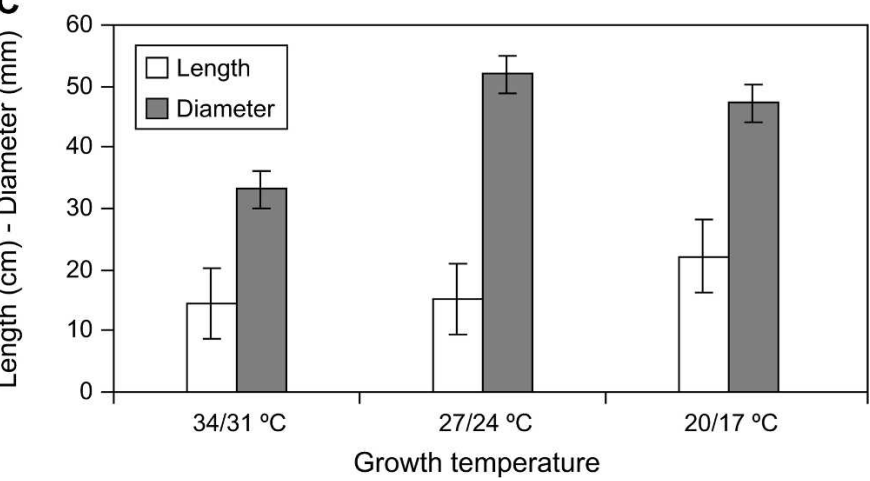

Fig. 2. (A) Periderm dry matter content (PDMC), (B) average root weight and yield, (C) and length and diameter of roots of 'Beauregard' sweetpotato at various growth temperatures. Each data point represents the mean of 12 observations. Weight calculated as the mean of 24 observations. Bars represent LSD values calculated at the $5 \%$ level. matter content were negatively correlated for uncured and cured roots (Table 1). The effect of temperature on dry matter content may be due to the increase in cell wall components or other cell components.

Yield, root weight, length, diameter, and biomass dry matter content were all affected by growth temperature (Figs. 2B,C and 3A). There was a positive correlation between biomass dry matter content and temperature (Table 1). Biomass dry matter content was higher for plants grown at higher temperatures (Fig. 3A). Because sweetpotato is a tropical plant, low temperatures negatively affect the development of the vegetative part of the plant, as well as the storage roots. However, yield of storage roots was lower for plants grown at the higher range of temperature than for plants grown at lower temperatures. There was a negative correlation between yield and growth temperature (Table 1). The highest yields were obtained from plants grown at an intermediate temperature, which was the optimal for the species. It is not surprising that at optimal temperatures, the plants had optimal root and shoot growth that resulted in higher storage root yield. Relatively low temperatures $\left(22-24^{\circ} \mathrm{C}\right)$
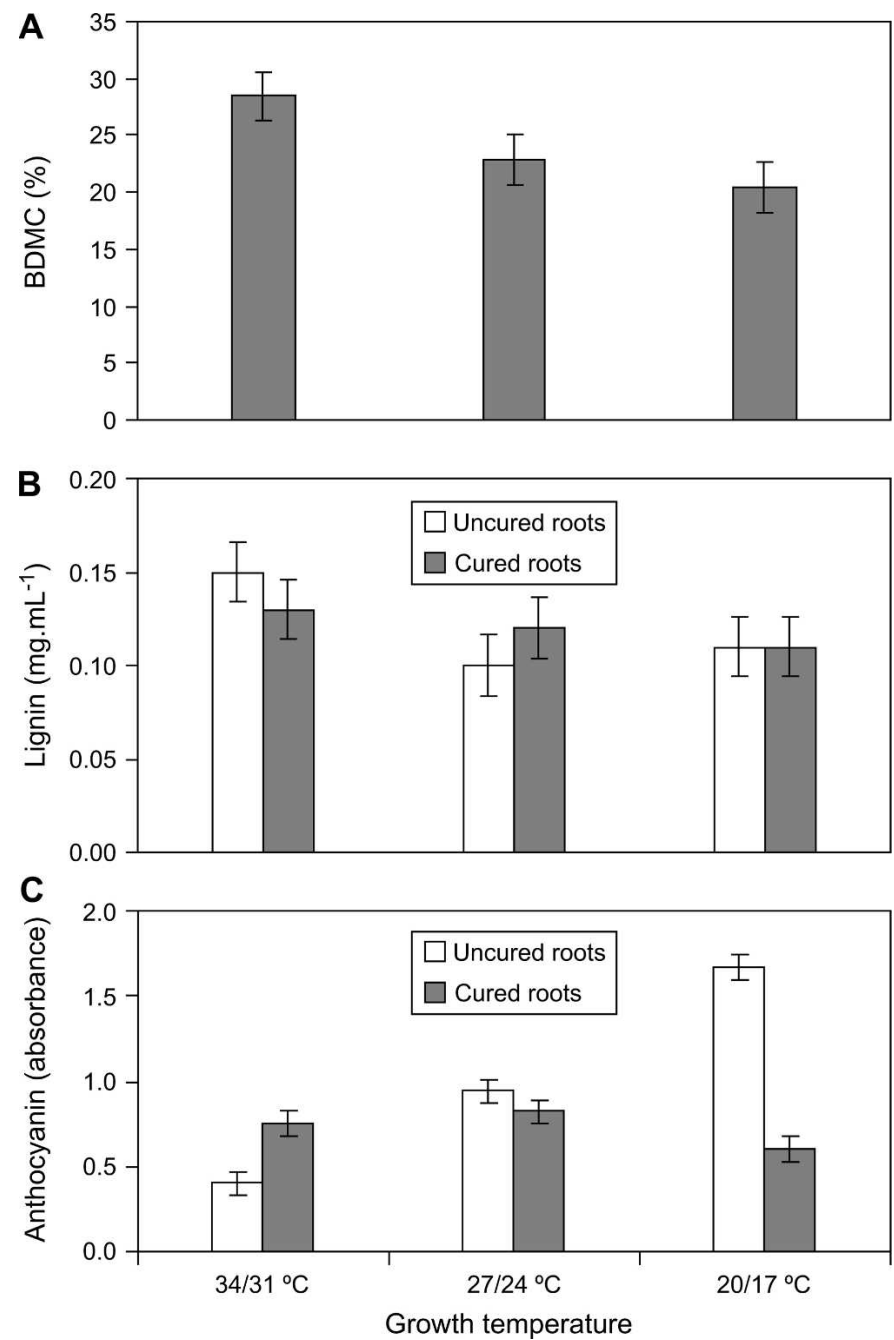

Fig. 3. (A) Biomass dry matter content (BDMC), (B) lignin content, (C) and anthocyanin content of 'Beauregard' sweetpotato at various growth temperatures. Each data point represents the mean of 12 observations for BDMC and of 6 observations for lignin and anthocyanin content. Bars represent LSD values calculated at the $5 \%$ level. 
result in rapid activity in the cambium and little lignification of the roots, a combination that favors the development of storage roots (Hahn and Hozyo, 1984). Spence and Humphries (1972) reported that the development of roots was more rapid at $25^{\circ} \mathrm{C}$ than at $30^{\circ} \mathrm{C}$, but no storage roots were formed at $15^{\circ} \mathrm{C}$. Early initiation of storage roots and rapid development are important in obtaining good production of storage roots. Slower growth rates might have been involved in the effect of temperature on yield. Plants grown at less than optimal temperatures would probably produce similar yield to those grown at optimal temperatures if they were allowed to grow longer.

Average root weight was negatively correlated with growth temperature (Table 1). Roots grown at the highest temperatures were lighter than roots grown at lower temperatures (Fig. 2B). Intermediate temperatures yielded roots with the same average weight of those grown at lower temperatures (Fig. 2B). The yield of storage roots per plant grown at lower temperatures, however, was significantly lower than the yield of storage roots grown at intermediate temperatures, thus the effect of temperature on yield apparently involved both number and weight of roots. The differences in root weight among temperature treatments could be the result of different patterns of photoassimilation from leaves to storage roots in response to effects of aerial and root zone temperatures on differentials between source capacity of the shoot and sink activity of the storage roots. Root length was not significantly different for the various temperature regimes evaluated (Fig. 2C).

Root diameter and temperature were negatively correlated (Table 1). Root diameter was lower in roots grown at higher temperatures than in roots grown at intermediate and low temperatures (Fig. 2C). After storage root initiation, development of the roots depends on the increase in both the number and size of the cells in the stele and the development of starch granules in the cells (Hahn and Hozyo, 1984). These events are affected by environmental factors, most notably temperature. Skin adhesion was affected by the size of the root, as indicated by a negative correlation for cured and uncured roots between skin adhesion and root diameter (Table 2). Smaller roots were more resistant to skin loss. Higher temperatures resulted in higher resistance to skin loss. It might be that root size does not directly determine susceptibility to skin loss but is a secondary effect of temperature. Another possibility is that skin adhesion could be a function of the rate of cell growth in the cell layers beneath the skin. In large roots, if the skin cells are dividing at a faster rate compared with the rate of the flesh cells, this might lead to skin separation.

Yield and biomass dry matter content were negatively correlated with temperature (Table 2). Yield in sweetpotato is determined by allocation of carbohydrates to the developing storage root. Conditions that result in excessive shoot growth usually result in reduced storage root formation. Higher temperatures favored vegetative growth and probably delayed the initiation of storage roots and translocation of carbohydrates to the growing root to result in lower yield.

There was a positive correlation between lignin content and temperature (Table 1). In fresh roots, lignin content in the periderm was higher in roots grown at higher temperatures compared with roots grown at lower temperatures (Fig. 3B). In cured roots, a similar effect of temperature on lignin content was seen, although there were no significant differences among treatments (Fig. 3B). The correlation between skin adhesion and lignin was not significant (data not shown), although there was a trend in which roots grown at higher temperatures had increased skin adhesion and increased lignin content. This might be a relationship that merits further study. Lignins confer compressive strength to the matrix of the cell walls (Whetten et al., 1998). In abscission zones, lignin may protect neighboring

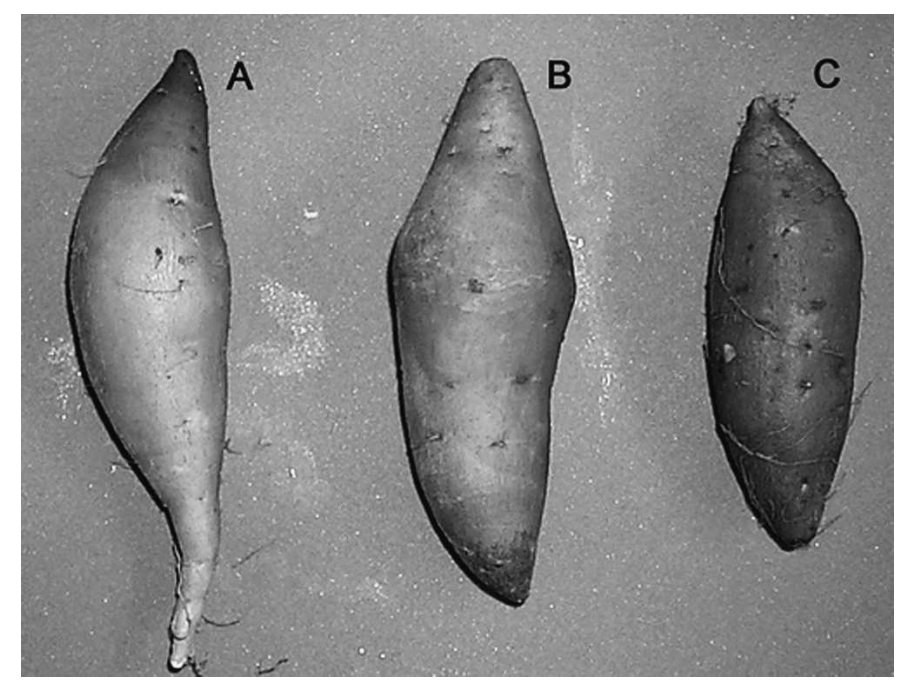

Fig. 4. Sweetpotato roots grown under various day/night temperatures $\left({ }^{\circ} \mathrm{C}\right)$ : (A) $34 / 31$, (B) $27 / 24$, and (C) 20/17.
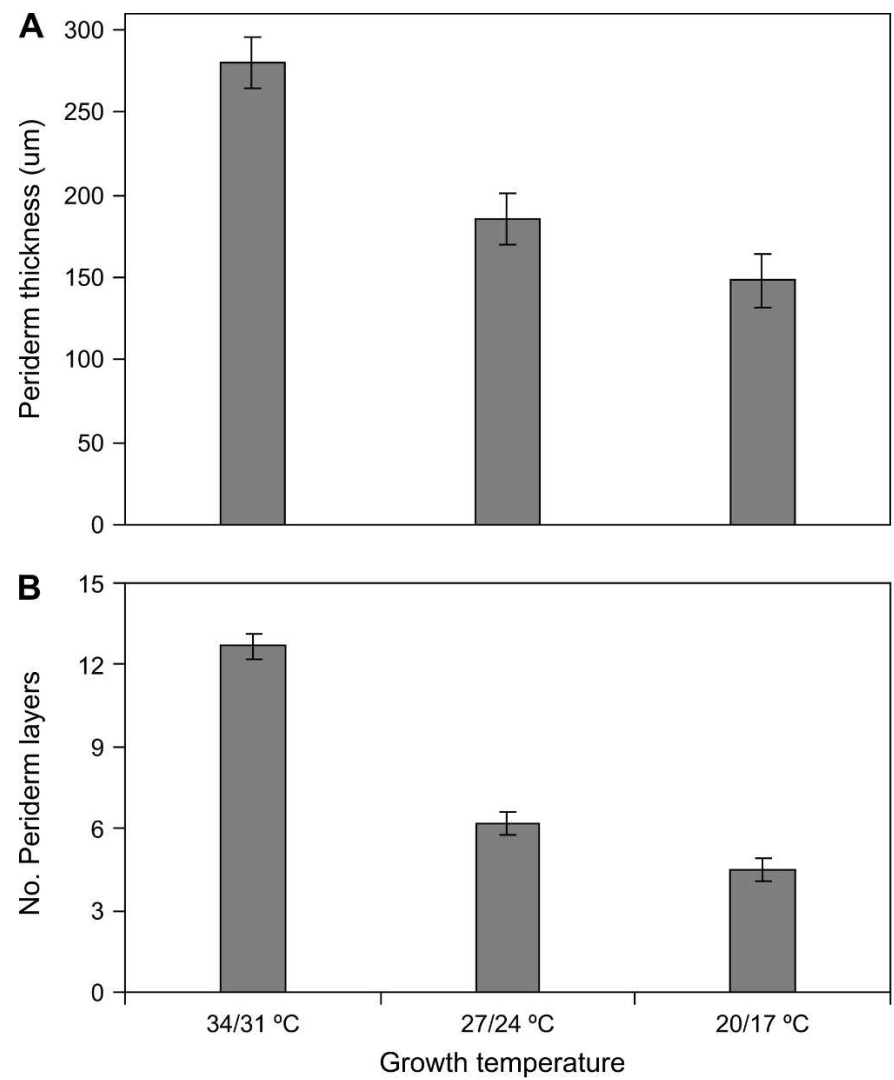

Fig. 5. (A) Periderm thickness and (B) number of periderm layers in sections of cured roots of 'Beauregard' sweetpotato at various growth temperatures. Each data point represents the mean of six observations. Bars represent LSD values calculated at the $5 \%$ level. 
cells from hydrolytic enzymes produced in the abscission layer (Sexton and Roberts, 1982).

Uncured roots from plants grown in the lower-temperature growth chambers had higher anthocyanin content compared with roots grown at higher temperatures (Fig. 3C). The difference in anthocyanin content was visibly evident by the color of the roots (Fig. 4). After curing, roots grown at higher and intermediate temperatures had similar anthocyanin contents, and these were higher than those of roots grown under cold conditions (Fig. 3C). It appears that curing decreases the anthocyanin content of roots grown at lower temperatures, remains relatively stable for roots grown at intermediate temperatures, and increases in roots grown at the highest temperatures. In uncured roots, anthocyanin content was negatively correlated with growth temperature (Table 1). It has been pointed out that the appearance of anthocyanins in different tissues can be a response to environmental variables, and concentration is a function of physiological age or stresses, such as osmotic stress or cold temperatures. In young leaves, anthocyanin accumulation occurs as a defense mechanism to increase coldhardiness (Chalker-Scott, 1999). In potato, storage at low temperatures increased the concentration of anthocyanins in the tubers (Lewis et al., 1999). Sweetpotato cultivar Ayamurasaki had increased anthocyanin content depending on soil temperature. There was a significant negative correlation between anthocyanin content of the storage root and soil temperature, and planting time was the factor that mainly influenced the anthocyanin contents of the roots (Kobayashi et al., 1998).

Growth temperature affected periderm thickness and the number of single-cell layers composing the periderm (Fig. 5A,B). Periderm thickness and number of periderm layers were positively correlated with temperature and with skin adhesion (Tables 1 and 2). Higher temperatures resulted in thicker periderm layers and a higher number of peridermal layers.

There have been reports of periderm thickness decreasing with increasing soil temperature (Webster et al., 1973). However, the number of peridermal cell layers remained constant. Higher temperatures increased resistance to skinning, and in this case the authors concluded that the increase in resistance to skinning was the result of a physiological change in the periderm and adjacent tissues rather than a structural change. In our study, resistance to skinning, number of cells of the periderm, and periderm thickness increased with increasing temperatures. These data seem to indicate that there is a link between periderm thickness, periderm layers, and the degree of skin adhesion. However, we cannot dismiss the possibility that the effect of temperature on increasing skin adhesion might be due to reasons other than the increase in periderm thickness and periderm layers. Such reasons could include changes in cell wall components and other structural changes.

Complete sections of periderm could only be obtained from cured roots. We observed that periderm separation always occurred at the site where periderm cells were different in infiltration and stainability from cortical cells.

Periderm anatomy in sweetpotato was affected by growth temperature (Fig. 6A-C). The periderm in sweetpotato is composed of three layers: phellem, phelloderm, and phellogen. The phellogen originates the phelloderm toward the inside of the root and the phellem toward the outside. The phellem is composed of several layers of cells devoid of starch granules and positioned in a radial manner toward the phellogen. The phelloderm is more difficult to identify as it resembles cortical cell and it usually is distinguished by the radial position of the cells in reference to the phellogen (Kono and Mizoguchi, 1982). Intermediate temperatures resulted in periderm layers with intermediate characteristics between the warmest and coldest conditions (Fig. 6B). However, the most striking differences are evident when periderm characteristics of roots grown at high and low temperatures are compared (Fig. 6A-C).

Plants grown at higher temperatures produced roots with a peridermal layer composed of a higher number of single-cell layers than that of roots grown at lower temperatures (Fig. 6A).
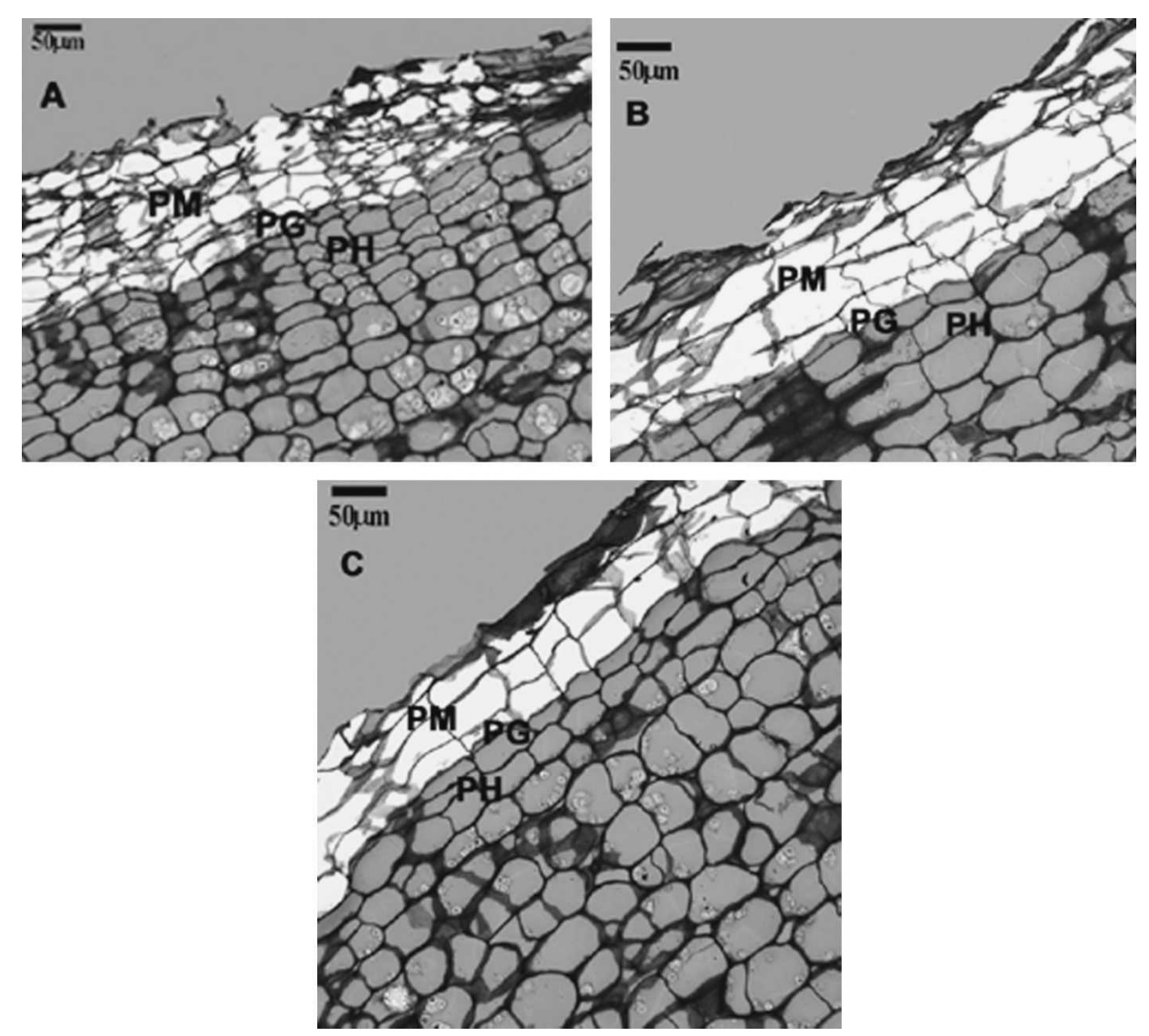

Fig. 6. Transections of sweetpotato roots grown under various temperatures stained with toluidine blue and basic fuchsine: (A) section of a root grown at $34 / 31^{\circ} \mathrm{C}$ day/night temperature; (B) section of a root grown at $27 / 24{ }^{\circ} \mathrm{C}$ day/night temperature; (C) section of a root grown at $20 / 17{ }^{\circ} \mathrm{C}$ day/night temperature. Periderm layers: phelloderm (ph), phellogen (pg), and phellem (pm). 
Sections from roots grown at higher temperatures show peridermal layers that are composed by 11-14 single-cell layers. The phelloderm layer, determined by the difference in stainability of this layer, was composed of more layers than the phelloderm of roots grown at lower temperatures.

The periderm of roots grown at intermediate temperatures is composed of about seven single-cell layers (Fig. 6B). In roots grown at cold temperatures, the periderm is composed of five to six single-cell layers (Fig. 6C).

Depending on growth temperature, there were differences in periderm infiltration. In general, peridermal cells are very resistant to infiltration, as evidenced by the change in background color of the different layers with the irregular distribution of the plastic resin throughout the section. However, periderm of roots grown at higher temperatures had higher numbers of peridermal single-cell layers infiltrated than did roots grown at lower temperatures.

The difference in infiltratability of the periderm layers in relation to growth temperature might indicate a change in structure that affects infiltration and stainability in these sections and thus, possibly, the degree of skin adhesion of these roots. Cell wall components such as suberin could have an effect on infiltration of the tissues, as sweetpotato periderm is composed of cells containing suberin (Walter and Schadel, 1983). Suberized tissues are usually resistant to infiltration.

Sections stained with ruthenium red, toluidine blue in citrate buffer, safranin $\mathrm{O}$ followed by orange $\mathrm{G}$, and the periodic acidSchiff reagent (PAS) showed that cell layers of the phellem are different in stainability that the phellogen, phelloderm, and cortical cells (data not shown; Villavicencio, 2002).

\section{Conclusions}

Skin adhesion, PG and PME activity, anthocyanin content, periderm and biomass dry matter content, yield, root weight, and root diameter in sweetpotato are affected by growth temperature. The highest temperature examined in this study yielded roots that were more resistant to skin loss, were smaller, and had a thicker periderm composed of more cell layers with a lower dry matter content than roots grown at lower temperatures. Growth temperature modified the color of the skin of the roots by affecting anthocyanin content. These findings validate the observations of growers that there is a seasonal effect on skinning. Warmer temperatures could result in roots that are less susceptible to skinning. Future studies need to be conducted to determine if the effect of temperature is the result of sustained warmer conditions during the growing season or if it can be achieved by a period of warm weather before harvest, similar to a natural curing in the soil. Other variables, such as soil moisture content in combination with temperature, may also influence the susceptibility to skinning of the roots.

Skin adhesion did not appear to be directly linked to cell wall enzyme activity, and the use of PG and PME as indicators of skin susceptibility at this point is not reliable. There were, however, a negative correlation between skin adhesion and PG activity and a positive one between skin adhesion and PME.

Skin adhesion appeared to be affected by root size, but it is not clear if this is a direct effect or if it is determined by the effect of temperature on skin adhesion and root diameter. Lignin and anthocyanin content were not directly related to skin adhesion. The difference in coloration of the root due to the variation in temperature is of commercial interest, as it affects the acceptance of the product by consumers. This study has shown that color of a given cultivar is somewhat dependent on growth temperature.

This study corroborates what other studies have shown regarding the effect of curing on skin setting. Curing improved skin adhesion of the storage roots, but the effect of curing was dependent on the plant growth temperature. Storage roots grown at lower temperatures were more susceptible to skin loss; however, curing significantly improved skin adhesion in these roots. A similar interaction between curing and temperature for PG and PME activity and lignin and anthocyanin contents was detected. A practical implication of these findings is that during colder seasons, it is even more important to cure sweetpotato roots to ensure skin setting and decreased susceptibility to skinning.

The histochemistry of the periderm of sweetpotato indicates a different anatomical and structural composition of the cell walls depending on growth temperature. More studies clarifying the effect of skin anatomy on the susceptibility to skinning are needed. Such studies will be valuable for breeders trying to incorporate beneficial traits in the cultivars that could help minimize the susceptibility of sweetpotatoes to skin loss.

\section{Literature Cited}

Artschwager, E. and R.C. Starrett. 1931. Suberization and woundperiderm formation in sweetpotato and gladiolus as affected by temperature and relative humidity. J. Agr. Res. 43:353-364.

Birnbaum, E.H. 1970. Characteristics of the periderm of roots of sweetpotato (Ipomoea batatas). MS Thesis. North Carolina State Univ., Raleigh.

Blankenship, S.M. and M.D. Boyette. 2002. Root epidermal adhesion in five sweetpotato cultivars during curing and storage. HortScience 37(2):374-377.

Bouwkamp, J.C., L.E. Scott, and W.L. Harris. 1972. Rapid determination of "skin-toughness" in sweetpotato. HortScience 7: 473-474.

Boyette, M.D., E.A. Estes, A.R. Rubin, and K.A. Sorensen. 1997. Maintaining the quality of North Carolina fresh produce. AG-413-10. North Carolina Coop. Ext. Serv. North Carolina State University, Raleigh.

Brummell, D.A. and M.K. Harpster. 2001. Cell wall metabolism in fruit softening and quality and its manipulation in transgenic plants. Plant Mol. Biol. 47:311-340.

Carpita, N.C. and D.M. Gibeaut. 1993. Structural models of primary cell walls in flowering plants: consistency of molecular structure with the physical properties of the walls during growth. Plant J. 3:1-30.

Chalker-Scott, L. 1999. Environmental significance of anthocyanins in plant stress responses. Photochem. Photobiol. 70(1):1-9.

Fukushima, R.S. and B.A. Dehority. 2000. Feasibility of using lignin isolated from forages by solubilization in acetyl bromide as a standard for lignin analyses. J. Anim. Sci. 78:3135-3143.

Hadfield, K.A. and A.B. Bennett. 1998. Polygalacturonases: many genes in search of a function. Plant Physiol. 117:337-343.

Hahn, S.K. and Y. Hozyo. 1984. Sweet potato, p. 551-558. In: P.R. Goldsworthy and N.M. Fisher (eds.). The physiology of tropical field crops. Wiley, New York.

Huber, D.J. and E.M. O’Donoghue. 1993. Polyuronides in avocado (Persea americana) and tomato (Lycopersicon esculentum) fruit exhibit markedly different patterns of molecular weight downshifts during ripening. Plant Physiol. 102:473-480.

Iiyama, K. and A.F.A. Wallis. 1990. Determination of lignin in herbaceous plants by an improved acetyl bromide procedure. J. Sci. Food Agr. 51:145-161.

Kobayashi, T., H. Ikoma, and H. Mochida. 1998. Effect of cultural conditions on anthocyanin content of purple-colored sweetpotato. Sweetpotato Res. Front. 6:2. 
Kono, Y. and T. Mizoguchi. 1982. The origin of root periderm in the sweet potato plant, Ipomoea batatas Lam. Jpn. J. Crop. Sci. 51(4): 535-541.

Levy, S. and L.A. Staehelin. 1992. Synthesis, assembly and function of plant cell wall macromolecules. Curr. Opin. Cell Biol. 4:856-862.

Lewis, C.E., J.R.L. Walker, and J.E. Lancaster. 1999. Changes in anthocyanin, flavonoid and phenolic acid concentration during development and storage of coloured potato (Solanum tuberosum L) tubers. J. Sci. Food Agr. 79:311-316.

Lulai, E.C. and P.H. Orr. 1993. Determining the feasibility of measuring genotypic differences in skin set. Amer. J. Potato Res. 70: 599-609.

Lulai, E.C. 2002. The roles of phellem (skin) tensile-related fractures and phellogen shear-related fractures in susceptibility to tuber skinning injury and skin-set development. Amer. J. Potato Res. 79:241-248.

Lulai, E.C. and T.P. Freeman. 2001. The importance of phellogen cells and their structural characteristics in susceptibility and resistance to excoriation in immature and mature potato tuber (Solanum tuberosum L.) periderm. Ann. Bot. (Lond.) 88:555-561.

Milner, Y. and G. Avigad. 1967. A copper reagent for the determination of hexuronic acids and certain ketohexoses. Carbohydr. Res. 4:359-361.

Morrison, I.M. 1972. A semi-micro method for the determination of lignin and its use in predicting the digestibility for forage crops. J. Sci. Food Agr. 23:455-463.

Pressey, R. and J.K. Avants. 1972. Multiple forms of pectinesterase in tomatoes. Phytochemistry 11:3139-3142.

Sanders, L., R. Child, P. Ulvskok, M. Albrechsten, and B. Borkhardt. 2001. Analysis of dehiscence zone endo-polygalacturonase in oilseed rape (Brassica napus) and Arabidopsis thaliana: Evidence for roles in cell separation in dehiscence and abscission zones, and in stylar tissues during pollen tube growth. Plant Mol. Biol. 46:469479.

Shi, Z., I.A. Bassa, S.L. Gabriel, and F.J. Francis. 1992. Anthocyanin pigments of sweet potatoes-Ipomoea batatas. J. Food Sci. 57(3): 755-770.

Schuch, W., J. Kanczler, D. Robertson, G. Hobson, G. Tucker, D. Grierson, S. Bright, and D. Bird. 1991. Fruit quality characteristics of transgenic tomato fruit with altered polygalacturonase activity. HortScience 26:1517-1520.
Sexton, R. and J.A. Roberts. 1982. Cell biology of abscission. Ann. Rev. Plant Physiol. 33:133-162.

Sirit, Y., B. Downie, A.B. Bennett, and K.J. Bradford. 1996. A novel exo-polygalacturonase is associated with radicle protrusion in tomato (Lycopersicon esculentum) seeds. Plant Physiol. 111 (suppl.): 161 (abstract).

Spence, J.A. and E.C. Humphries. 1972. Effects of moisture supply, root temperature and growth regulators on photosynthesis of isolated root leaves of sweet potato Ipomoea batatas. Ann. Bot. (Lond.) 36: $115-121$.

Taylor, J.E., G.A. Tucker, Y. Lasslett, C.J.S. Smith, C.M. Arnold, C.F. Watson, W. Schuch, D. Grierson, and J.A. Roberts. 1990. Polygalacturonase expression during leaf abscission of normal and transgenic plants. Planta 183:133-138.

Thomas, J.F. and R.J. Downs. 1991. Phytotron procedural manual for controlled-environment research at the southeastern plant environment laboratory. Tech. Bul. 244 (revised). North Carolina State University, North Carolina Agricultural Research Service, Raleigh.

Viles, F.J. and L. Silverman. 1949. Determination of starch and cellulose with anthrone. Anal. Chem. 21(8):950-953.

Villavicencio, L.E. 2002. Physiological aspects of skin adhesion in sweetpotato (Ipomoea batatas (L.) Lam.). PhD Diss. North Carolina State University, Raleigh.

Walter, Jr., W.M., and W.E. Schadel. 1982. A rapid method for evaluating curing progress in sweet potatoes. J. Amer. Soc. Hort. Sci. 107(6):1129-1133.

Walter, Jr., W.M., and W.E. Schadel. 1983. Structure and composition of normal skin (periderm) and wound tissue from cured sweetpotatoes. J. Amer. Soc. Hort. Sci. 108(6):909-914.

Webster, E.G., M.E. Wright, and M.E. Austin. 1973. Sweetpotato periderm failure in response to soil moisture and temperature. HortScience 8(3):226-227.

Whetten, R.W., J.J. MacKay, and R.R. Sederoff. 1998. Recent advances in understanding lignin biosynthesis. Annu. Rev. Plant Physiol. Plant Mol. Biol. 49:585-609.

Willats, W.G.T., L. McCartney, W. Mackie, and J.P. Knox. 2001. Pectin: cell biology and prospects for functional analysis. Plant Mol. Biol. 47:9-27.

Wood, P.L. and I.R. Siddiqui. 1971. Determination of methanol and its application to measurement of pectin ester content and pectinmethylesterase activity. Anal. Biochem. 39:418-428. 